ISSN: 2224-0616

Int. J. Agril. Res. Innov. Tech. 11(1): 117-122, June 2021

DOI: https://doi.org/10.3329/ijarit.v11i1.54474
OPEN $\%$ ACCESS

Available online at https://ijarit.webs.com https://www.banglajol.info/index.php/IJARIT

\title{
Effects of supplementing lactating camels with Acacia tortilis pods and 'Chalbi salt' on milk yield and calf growth in the peri-urban area of Marsabit town, Kenya
}

\author{
J.I. Sagala ${ }^{1 *}$, C.K. Gachuiri ${ }^{1}$, S.G. Kuria ${ }^{2}$ and M.M. Wanyoike ${ }^{1}$ \\ Received 30 April 2021, Revised 18 June 2021, Accepted 23 June 2021, Published online 30 June 2021
}

\begin{abstract}
A B S T R A C T
Camel milk production and marketing within the peri-urban areas within pastoral areas is emerging and has high potential due to sendentarization and urbanization of an increasing number of local inhabitants. Performance of grazing camels in these areas is poor due to inadequate feed resources, particularly during the dry season. The objective of this study was to determine the effect of supplementing lactating camels with milled Acacia tortilis pods and 'Chalbi salt' on milk yield, calf growth and its economic potential in the peri-urban area of Marsabit town, Kenya. Twenty Somali camels in early lactation (1-4 weeks postpartum) and parities 2 or 3 and their calves were recruited for the study. The dams and their calves were penned and fed individually with the supplements where applicable. The treatments were: browsing only (B), browsing and 'Chalbi salt' (BC), $2 \mathrm{~kg} /$ day milled Acacia tortilis pods, 'Chalbi salt' and browsing (BC2A) and $4 \mathrm{~kg} /$ day milled Acacia tortilis pods, 'Chalbi salt' and browsing (BC4A). Five camels were randomly allocated to each treatment based on initial live weight in a completely randomized design and data collection done for 90 days. During each milking, the two left or right quarters were alternately reserved for the calf, while the remaining two were milked by hand. Milk yields were recorded daily in the morning and evening for 90 days while the calves were weighed on weekly basis for the same period. The overall total mean milk yield during the experimental period ranged from 233.0 to 298.o litres during the short rains and dry season, respectively. The mean calf weight gains over the study period were $15.2,19.0,32.2$ and $39.0 \mathrm{~kg}$ for $\mathrm{B}, \mathrm{BC}, \mathrm{BC} 2 \mathrm{~A}$ and $\mathrm{BC} 4 \mathrm{~A}$, respectively, with $\mathrm{BC} 4 \mathrm{~A}$ and $\mathrm{BC} 2 \mathrm{~A}$ being higher than $\mathrm{B}$. Supplementing camels under treatment $\mathrm{BC} 4 \mathrm{~A}$ was profitable as it resulted in both higher milk yield and calf weight gain and hence positive net gain.
\end{abstract}

Keywords: Acacia tortillis pods, Calf growth, Camels, Chalbi salt, Milk yield.

${ }^{1}$ University of Nairobi, College of Agriculture and Veterinary Sciences, Box 29053, Kabete, Kenya.

${ }^{2}$ Kenya Agricultural and Livestock Research Organization, Kiboko station, Box 12-90138, Makindu, Kenya.

*Corresponding author’s email: josphat.sagala@kalro.org (J.I. Sagala)

Cite this article as: Sagala, J.I., Gachuiri, C.K., Kuria, S.G. and Wanyoike, M.M. 2021. Effects of supplementing lactating camels with Acacia tortilis pods and 'Chalbi salt' on milk yield and calf growth in the peri-urban area of Marsabit town, Kenya. Int. J. Agril. Res. Innov. Tech. 11(1): 117-122. https://doi.org/10.3329/ijarit.v11i1.54474

\section{Introduction}

The camel (Camelus dromedarius) is supremely adapted to arid and semi-arid regions. It thrives in these harsh environments due to its tolerance to high ambient temperatures, drought, disease and by browsing on a wide range of plant species least utilized by other livestock (Morton, 1984; Bornstein and Younan, 2013). Frequent droughts have led to high losses of cattle, sheep and goats in the fragile ASALs of northern Kenya (Aklilu and Wekesa, 2002) with camels only marginally affected. The camel's ability to survive drought periods surpasses any other domestic livestock in the arid lands (Huho et al., 2011). Camels in
Kenya are reared under three production systems; nomadism characterized by seasonal migration, a more intensive camel dairying practiced in private camel ranches and the periurban system, which is spreading too many areas including Marsabit County (Noor et al., 2012). In 2011, camel milk production in Kenya was estimated at 553 million litres ( $7 \%$ of the national total) worth about KES 16 billion (Behnke and Muthami, 2011) and is currently estimated at 876 million litres (FAO, 2017). Daily milk yield of camels vary from 3.5 litres under desert conditions to 40.0 litres under very intensive 
management (Khan, et al., 2003; Farah et al., 2004, Adongo et al., 2013).

One of the main constraint to peri-urban camel production system is seasonality of feed availability, and where available is of poor quality. Nutritional supplementation of the dams during dry season is one alternative strategy to mitigate against energy and protein deficiencies using local feed resources like Acacia tortilis pods and local mineral salt to enhance milk production (Lengarite et al., 2014). Inadequacy of essential minerals like $\mathrm{Na}, \mathrm{Ca}, \mathrm{K}, \mathrm{Zn}$ and $\mathrm{Cu}$ in camel nutrition as reported by Kuria et al. (2004), lack of camel supplementary feeding and inadequate nutrient availability in most forage plants (Noor et al., 2012) as well as camel milk spoilage (Matofari, 2013) generally affect camel productivity in pastoral areas. The objective of this study was to determine the effect of supplementing lactating camels with Acacia tortilis pods and 'Chalbi salt' on milk production, calf growth and its cost/benefits in the peri-urban camel production system.

\section{Materials and Methods}

\section{Study area}

The study was conducted in Karare sub-location of Marsabit County, Kenya which, lies between latitude $\mathrm{O}^{\circ}{ }^{1} 9^{\prime}$ North and $\mathrm{O}^{\circ}{ }^{\circ} 1^{\prime}$ 'North, and longitude $37^{\circ} 89^{\prime}$ East and $37^{\circ} 76^{\prime}$ East with a mean elevation of $874 \mathrm{~m}$ above sea level. The sub-location covers an area of approximately 233 square kilometers with a population of about 4,628 people as per the 2019 census (KNBS, 2019). The mean annual precipitation in the study area ranged between $200 \mathrm{~mm}$ and 1,000 $\mathrm{mm}$ per annum in the plains and foot slopes of the mountainous areas, respectively, and is distributed between two seasons, long rains from March to May and the short rains occurring from October to December, with dry periods between June to September. Soils are of low density, poor texture, shallow with low organic content. There are diverse browses ranging from trees, shrubs and forbs in the area. The study area experiences tropical climatic conditions with temperatures ranging from a minimum of $10.1^{\circ} \mathrm{C}$ to a maximum of $30.2^{\circ} \mathrm{C}$ with an annual average of $20.1^{\circ} \mathrm{C}$.

\section{Identification of study site and camels}

The grazing/browsing site selected for the study was called Mincho Minyi and was purposely selected due to good terrain, accessibility from the main road, near a watering point and presence of an emerging peri-urban camel production system with large herds of camels. The area is also accessible to Marsabit town where there is a niche market for camel milk provided by the highly populated sedentarized pastoral communities. The study was done during the short rains season (December 2018 to
January 2019) and the dry season (February to March 2019).

\section{Management of experimental camels}

Twenty Somali camels in early stage of lactation (1-4 weeks post-partum) and parities 2 or 3 were selected from two large herds raised under the peri-urban production system. Prior to the commencement of the experiment, all the selected lactating camels were ear-tagged. Their live weights were estimated using the formula; Heart girth (m) x Abdominal girth (m) $\mathrm{x}$ shoulder height (m) x 50 (Schwartz et al., 1983) and grouped according to the initial weight. The calves were weighed using a weighing dial balance (original Hanson, Model No.21, Trademark No.595766, India) suspended on a metallic tripod stand with the help of straps and a gunny bag. The lactating camels were treated against ecto-parasites using Ectopor ${ }^{\circledR}$, Triatix ${ }^{\circledR}$ and endo-parasites using Ivermectin ${ }^{\circledR} \quad 1 \%$ (Coopers limited). The camels were also injected with Triquin $^{\circledR}$ (a prophylaxis measure against trypanosomiasis). The lactating camels were placed in 4 treatment groups of 5 each based on weight and parity: Grazing only (B); grazing and $140 \mathrm{~g}$ of Chalbi salt (BC); grazing, $140 \mathrm{~g}$ of Chalbi salt and $2 \mathrm{~kg} /$ day milled Acacia tortilis pods (BC2A); $140 \mathrm{~g}$ of Chalbi salt and $4 \mathrm{~kg} /$ day milled Acacia tortilis pods $\left(\mathrm{BC}_{4} \mathrm{~A}\right)$. Calves remained behind near the night enclosure and fed from nearby shrubs. They were also separated from their dams at night and were weighed on weekly basis. The adult camels were only weighed at the start and end of the study and weight differences were used to compute the weight gain or loss during the supplementation period. Data collection was for 90 days. The animals were housed individually in enclosures (corral) made of thorny woody branches reinforced with chain link and fed individually from troughs made from fabricated metal drums/tanks. All the 20 camels were also grazed/browsed for 8 hours daily in the free-range communal pastures of Karare.

\section{Milking}

Milk yield was estimated through hand milking of two quarters at 0800 hrs and 1800 hrs. During each milking, the two left or right side quarters were alternately reserved for the calf, while the remaining two were milked. Calves were used to stimulate milk letdown before milking and thereafter left to suckle their dams for at least 30 minutes after the morning and evening milking. Milk yield was measured using graduated milk jars and recorded daily in the morning and evening for 90 days. Prior to milking, the milking muzzy cans and traditional milking containers "Mbasige" were thoroughly cleaned and rinsed with hot water. 


\section{Processing of the feed supplements}

\section{Milling of Acacia tortilis pods}

Fully ripened pods of Acacia tortilis were harvested from trees by shaking and use of long looped sticks in the communal grazing land of Karare and Soriadi, spread on polythene sheet and all foreign material and damaged pods separated and discarded. The Acacia tortilis pods were milled using a twin-engine portable grinder into a coarse meal consisting of seeds and husks (to pass through $1 \mathrm{~mm}$ screen size) of the grinder and stored in gunny bags in a cool and dry storage shed. Two workers working 5 hours for 23 days did milling of the pods.

\section{Grinding of Chalbi salt granules}

Local salt (Chalbi salt) is a natural mineral source found in Chalbi desert of Marsabit County, Kenya, and is naturally accessed by grazing camels. Chalbi salt was bought from Marsabit town where it is sold to livestock keepers after being scooped from the Chalbi desert in Kenya. The solid particles of the salt were ground using a mortar, pestle to a fine texture, and stored in gunny bags in a cool and dry shed. Grinding of large flakes of the Chalbi salt with pestle and mortar took one hour.

\section{Gross margin analysis}

A simple gross margin analysis (GMA) and cost benefit ratio (CBR) of combining Acacia tortilis pods and Chalbi salt was done to ascertain the viability of the supplementation. Income from growth rate (meat) was calculated by subtracting the total weight gains of $\mathrm{BC}, \mathrm{BC}_{2} \mathrm{~A}$ and $\mathrm{BC}_{4} \mathrm{~A}$ from $B$. The differences in weight gains from the supplemented groups were translated into meat
( $\mathrm{kg}$ ) by multiplying with dressing percentage of $55 \%$ (Kurtu, 2004). The total quantity of meat $(\mathrm{kg})$ of all supplemented groups was then multiplied by the price of meat (using price of meat at the local butchery at study time which was Ksh 400/ $\mathrm{kg}$ (3.97 US\$ equivalent)) to get the conferred benefit to the farmer.

Income from additional milk (litres) was calculated by subtracting the milk increment because of supplementation of $\mathrm{BC}, \mathrm{BC} 2 \mathrm{~A}$ and BC4A from B. The difference for milk (litres) was multiplied by market price of milk (price of milk in the study area was Ksh 100/litre (0.993 US\$ equivalent) to get increased income to the farmer from additional milk. Gross margin was obtained by subtracting the total cost of all the inputs from the benefit/income from milk sales and growth rate (meat). The BCR was obtained by taking the benefits/income gained because of supplementation versus the costs incurred in executing the study.

\section{Data analysis}

The data collected on daily milk yield (litres) and weekly calf weights (kilograms) was analysed using GenStat (2012) software analysis of variance (ANOVA) procedures in a completely randomized design (CRD). The treatment means were separated using the least significance difference (LSD) at $5 \%$.

\section{Results and Discussion}

\section{Effect of Acacia tortilis pods and 'Chalbi salt' supplementation on milk production}

The mean milk yield of the lactating camels on different treatments is shown in Table 1.

Table 1. Milk yield (litres) of camels fed different diets during the short rains and dry season.

\begin{tabular}{|c|c|c|c|}
\hline \multirow[t]{2}{*}{ Supplement diets } & \multicolumn{2}{|c|}{ Milk (Litres) } & \multirow[t]{2}{*}{ Total yield } \\
\hline & Short rains season & Dry season & \\
\hline B & $214.9^{\mathrm{a}}$ & $234.9^{\mathrm{a}}$ & $449.8^{\mathrm{a}}$ \\
\hline $\mathrm{BC}$ & $232.6^{\mathrm{a}}$ & $286.5^{\mathrm{ab}}$ & $519.1^{\mathrm{ab}}$ \\
\hline $\mathrm{BC} 2 \mathrm{~A}$ & $214.2^{\mathrm{a}}$ & $318.0^{\mathrm{ab}}$ & $532.2^{\mathrm{ab}}$ \\
\hline $\mathrm{BC} 4 \mathrm{~A}$ & $270.4^{\mathrm{a}}$ & $351.1^{\mathrm{b}}$ & $621.5^{\mathrm{b}}$ \\
\hline Mean & 233.0 & 298.0 & 531.0 \\
\hline S.E & 31.7 & 30.5 & 61.0 \\
\hline$P$ value & 0.571 & 0.086 & 0.297 \\
\hline
\end{tabular}

B-Control, BC-Control+Chalbi, BC2A-Control+Chalbi+2kg Acacia pods, BC4A-Control+Chalbi+4kg Acacia pods. ${ }^{a b}$ Column means with different superscripts are significantly different $(P \leq 0.05)$. Short rains season (December 2018 to January 2019) and the dry season (February to March 2019).

The mean milk yield of camels on different treatments during the short rain and dry season was 233.0 and 298.o litres, respectively. The milk yield differed significantly during the dry season with the supplemented camels (BC4A) having higher milk yield compared to the control (B). However, treatment $\mathrm{BC} 2 \mathrm{~A}$ and $\mathrm{BC}$ was not significantly different from the control (B) implying that inclusion of Chalbi salt alone, and Chalbi salt and $2 \mathrm{~kg}$ Acacia tortilis pods in addition to browsing did not have a significant influence on the milk yield during the dry season. The increase in milk yield during the dry season can be attributed to the supplementation. The 
effects of supplementation was realized during the dry season as this was the period of feed deficits hence dams supplemented in $\mathrm{BC} 4 \mathrm{~A}$ in addition to basal diets from browsing produced more milk than the other 3 treatments. Farah et al. (2004) also reported variation in milk yield in different seasons.

Dams in treatment $\mathrm{BC}, \mathrm{BC} 2 \mathrm{~A}$ and $\mathrm{BC} 4 \mathrm{~A}$ had a average yield of $5.77,5.91$ and 6.90 litres of milk per day compared to 4.99 for treatment B. Dell'Orto et al. (2000) reported a lower milk yield of 3.09 litres/day in Ol-Maisor ranch in Kenya where camels were supplemented with 200grams of a mineral supplement containing both macro and micro nutrients. Milk yield of 6.22 litres/day reported by Babiker and Zubeir (2014) in the semi-intensive camel production system in Sudan in herds supplemented with groundnut cake and Sorghum bicolor was comparable to the milk yield observed in treatment $\mathrm{BC} 4 \mathrm{~A}$ in the current study. However, studies by Noor (2013) in Kenya reported lower milk yield of 3.8 litres/day in lactating dams supplemented with a mixture of $20 \%$ milled Acacia tortilis pods, 3\% urea, 65\% barley straw, $10 \%$ molasses and $2 \%$ dairy mineral lick in addition to browsing compared to the dams supplemented with milled Acacia tortilis pods and Chalbi salt in this study. The animals supplemented under $\mathrm{BC} 4 \mathrm{~A}$ showed an increase in milk production. Therefore, the increase in milk production in the current study was attributed to Acacia tortilis pods and Chalbi salt supplementation in agreement with the findings of Hashi et al. (1995) and Noor (2013) who reported that productivity can be enhanced by supplementing grazing ruminants.

\section{Effect of Acacia tortilis pods and Chalbi salt supplementation on calf growth}

Table 2. Weight gains $(\mathrm{kg})$ of camel calves for dams fed on different diets.

\begin{tabular}{|c|c|c|c|}
\hline \multirow[t]{2}{*}{ Supplement diets } & \multicolumn{2}{|c|}{ Calf weight gain $(\mathrm{kg})$} & \multirow{2}{*}{$\begin{array}{l}\text { Total weight } \\
\text { gain (kg) }\end{array}$} \\
\hline & Short rain season & Dry season & \\
\hline $\mathrm{B}$ & $6.2^{\mathrm{c}}$ & $9.0^{\mathrm{b}}$ & $15.2^{\mathrm{c}}$ \\
\hline $\mathrm{BC}$ & $8.8^{b c}$ & $10.2^{\mathrm{ab}}$ & $19.0^{\mathrm{bc}}$ \\
\hline $\mathrm{BC} 2 \mathrm{~A}$ & $17.0^{\mathrm{ab}}$ & $15.2^{\mathrm{ab}}$ & $32.2^{\mathrm{ab}}$ \\
\hline $\mathrm{BC} 4 \mathrm{~A}$ & $23.0^{\mathrm{a}}$ & $16.0^{\mathrm{a}}$ & $39.0^{\mathrm{a}}$ \\
\hline Mean & 13.8 & 12.6 & 26.4 \\
\hline S.E & 2.48 & 1.564 & 3.44 \\
\hline$P$ value & $<0.001$ & 0.012 & $<0.001$ \\
\hline
\end{tabular}

B-Control, BC-Control+Chalbi, BC2A-Control+Chalbi+2kg Acacia pods, BC4A-Control+Chalbi+4kg Acacia pods. ${ }^{a b}$ Column means with different superscripts within the season are significantly different $(P \leq 0.05)$.

The overall mean calf weight gains from dams on different diets during the study period were 13.8 and $12.6 \mathrm{~kg}$ during the short rains and dry season, respectively (Table 2 ). The mean total calf weight gains were $15.2,19.0,32.2$ and $39.0 \mathrm{~kg}$ for $\mathrm{B}, \mathrm{BC}, \mathrm{BC} 2 \mathrm{~A}$ and $\mathrm{BC} 4 \mathrm{~A}$, respectively, with $\mathrm{BC} 4 \mathrm{~A}$ and $\mathrm{BC} 2 \mathrm{~A}$ being higher than B. Similarly, BC4A was significantly different from $\mathrm{BC}$ and $\mathrm{B}$. During the short rains season, calves under $\mathrm{BC} 4 \mathrm{~A}$ recorded a significantly higher weight gain than the other 3 diets. This higher weight gain can be attributed to the superior feeding of dams that resulted in more milk. The overall superior performance exhibited by the supplemented groups can be largely attributed to the high $\mathrm{CP}$, energy, $\mathrm{BF}$ and mineral content provided by the milled Acacia tortilis pods and Chalbi salt which enhanced milk yield in dams and this was reflected in the higher calf growth. The differences in calves weight gain during these two seasons was in line with the findings by Iqbal and Khan (2001) who reported that disparities in calf weight gain is attributed to variation in nutrition which normally comes from supply of milk from their dams.

Treatment $\mathrm{BC}, \mathrm{BC} 2 \mathrm{~A}$, and $\mathrm{BC} 4 \mathrm{~A}$ recorded higher growth rates compared to $11.33 \mathrm{~kg}$ for a similar period for Marecha calves raised under semi- intensive system on gram residues of Cicer arientinum in addition to browsing as reported by Faraz et al. (2017). Calves whose dams were supplemented (treatment $\mathrm{BC} 2 \mathrm{~A}, \mathrm{BC} 4 \mathrm{~A}$ and $\mathrm{BC}$ ) recorded weight gains of $52.8 \%, 61.0 \%$ and 20.0\%, respectively, over control (B) and thus animals supplemented under $\mathrm{BC} 4 \mathrm{~A}$ had an increase in milk production which translated to high growth rate of the calves

Calves in treatment $\mathrm{B}, \mathrm{BC}, \mathrm{BC} 2 \mathrm{~A}$ and $\mathrm{BC} 4 \mathrm{~A}$ had daily weight gains of 169, 211, 358 and 433 grams per day, respectively. The weight gains of calves under treatment $\mathrm{B}$ and $\mathrm{BC}$ were comparable to 281 and 168 grams for male and female calves raised under traditional pastoral production system as reported by Mungai et al. (2010).

\section{Cost benefit analysis of Acacia tortilis pods and Chalbi salt supplementation}

A simple gross margin (GMA) and benefit cost ratio (BCR) analysis of combining Acacia tortilis pods and Chalbi salt was done to ascertain the viability of the supplementation. Through supplementing camels in the peri-urban area, camel keepers are likely to realize enhanced income accruing from higher growth rate (meat) and milk sales (Table 4 and 5). 
Table 3. Total variable costs of supplementing the camels.

\begin{tabular}{|c|c|c|}
\hline Unit & Quantity & Amount (Ksh) \\
\hline Cost of Chalbi salt & $\begin{array}{l}5 \text { camels* } 18 \text { times* } 140 \mathrm{~g} \text { of salt* } 100 \\
\mathrm{ksh} / \mathrm{kg}^{*} 3 \text { groups/treatments }\end{array}$ & 3,780 \\
\hline Labour cost of Chalbi salt grinding & & 57 \\
\hline Acacia tortilis purchase costs & $2700 \mathrm{kgs}^{*} 12.33 \mathrm{ksh} / \mathrm{kg}$ & 33,291 \\
\hline Acacia tortilis collection costs & $\begin{array}{l}6 \mathrm{~kg} \text { pods daily*}\left(5 \text { camels }^{*} 90 \text { days }\right) \text { for } 2 \\
\text { groups }\end{array}$ & 13,572 \\
\hline Acacia tortilis transportation costs & & 8,200 \\
\hline Acacia tortilis milling costs & & 9,570 \\
\hline Acacia tortilis milling labour costs & 230 hours*Ksh 56.55/hour & 13,007 \\
\hline Feeding of supplements labour costs & 360 hours*Ksh $56.55 /$ hour & 20,358 \\
\hline Total & & 101,835 \\
\hline
\end{tabular}

Ksh 10o.75 was equivalent to one US\$ during the study period

Table 4. Total calf weight gain $(\mathrm{kg})$ during the study period.

\begin{tabular}{|l|c|c|c|c|c|}
\hline $\begin{array}{l}\text { Supplement } \\
\text { Diets }\end{array}$ & $\begin{array}{l}\text { Calf weight }(\mathrm{Kg}) \\
\text { Short rain season }\end{array}$ & $\begin{array}{c}\text { Dry season } \\
\text { Sotal weight }\end{array}$ & $\begin{array}{c}\text { Change in } \\
\text { geight(kg) }\end{array}$ & $\begin{array}{c}\text { Overall } \\
\text { gain }(\mathrm{kg})\end{array}$ \\
\hline B & 31 & 45 & 76 & & \\
\hline BC & 44 & 51 & 95 & $19(95-76)$ & \\
\hline BC2A & 85 & 76 & 161 & $85(161-76)$ & \\
\hline BC4A & 115 & 80 & 195 & $119(195-76)$ & $223^{\#}$ \\
\hline
\end{tabular}

\#assuming dressing weight of 55\% (Abebe et al., 2002) the extra meat realized $123 \mathrm{~kg}$ meat at cost of Ksh 40o/kg was Ksh 49,200 (488.34 US\$ equivalent)

With supplementing lactating camels with Acacia in additional milk. The milk yield (litres) in both tortilis pods and 'Chalbi salt', camel keepers the short rains and dry season are shown in Table realised an income of Ksh 49,200 (488.34 US\$ equivalent) from meat. The other benefit to the 5 . camel keeper resulting from supplementation is

Table 5. Milk yield (litres) during the short rains and dry season.

\begin{tabular}{|c|c|c|c|c|c|}
\hline \multirow[t]{2}{*}{ Supplement Diets } & \multicolumn{2}{|c|}{ Milk (Litres) } & \multirow{2}{*}{$\begin{array}{l}\text { Total Milk } \\
\text { (litres) }\end{array}$} & \multirow{2}{*}{$\begin{array}{l}\text { Change in } \\
\text { milk yield } \\
\text { (litres) }\end{array}$} & \multirow{2}{*}{$\begin{array}{l}\text { Overall } \\
\text { yield } \\
\text { (litres) }\end{array}$} \\
\hline & $\begin{array}{c}\text { Short rain } \\
\text { season }\end{array}$ & Dry season & & & \\
\hline B & $1,074.4$ & $1,174.6$ & $2,249.0$ & & \\
\hline $\mathrm{BC}$ & $1,162.9$ & $1,432.4$ & $2,595 \cdot 3$ & 346.3 & \\
\hline $\mathrm{BC} 2 \mathrm{~A}$ & $1,071.0$ & $1,590.0$ & $2,661.0$ & 412.0 & \\
\hline $\mathrm{BC} 4 \mathrm{~A}$ & $1,352.2$ & $1,755.4$ & $3,107.6$ & 858.6 & $1,617 \#$ \\
\hline
\end{tabular}

\# the extra milk (litres) realized was 1617 litres at cost of Ksh 100/litre was Ksh 161,70o (1,604.96US\$ equivalent)

With supplementing lactating camels with Acacia tortilis pods and 'Chalbi salt', camel keepers

realised an income of Ksh 161,700 (1,604.96US\$

Table 6. Summary of GM and BCR.

\begin{tabular}{|l|c|}
\hline Item & Amount (Ksh) \\
\hline Benefits (Milk and calves weight gain value) & 210,900 \\
\hline Costs & 101,835 \\
\hline Gross Margin & 109,065 \\
\hline Benefit cost ratio & 2.1 \\
\hline
\end{tabular}

\section{Conclusion}

Supplementing grazing lactating camels with Acacia tortilis pods and Chalbi salt in addition to browsing increased milk yield and calf weight gain. Capacity building on the sustainable utilization of these potential locally available protein and mineral feed resources is paramount to enhance milk yield, which translates to high growth rates of the calves among the peri-urban camel keepers in the pastoral areas where camel feed supplements is a challenge. The economic gains from use of these local feed resources can bridge the gap of inadequate feed resources especially during the dry season. 


\section{Acknowledgement}

This study was financed by the United States Agency for International Development through the Kenya Agricultural and Livestock Research Organization. The authors express their deep gratitude to the peri-urban camel keepers for availing their camels for this study.

\section{References}

Abebe, W., Getinet, A.M. and Mekonnen, H.M. 2002. Study on live weight, carcass weight and dressing percentage of Issa camels in Ethiopia. Revue de médecine vétérinaire. 153(11): 713-716.

Adongo, A.O., Coppock, D.L. and Wayua, F.O. 2013. Simple evaporative cooling method reduces bacterial content of traditionally marketed camel milk in Isiolo County, Kenya. African J. Food Agric. Nutri. Dev. 13(1): 7213-7224. https://doi.org/10.18697/ajfand.56.12460

Aklilu, Y. and Wekesa, M. 2002. Drought, livestock and livelihoods: lessons from the 1999-2001 emergency response in the pastoral sector in Kenya. London: Overseas Development Institute. 6p.

Babiker, W.I. and El-Zubeir, I.E. 2014. Impact of husbandry, stages of lactation and parity number on milk yield and chemical composition of dromedary camel milk. Emirates J. Food Agric. 26(4): 333-341. https://doi.org/10.9755/ejfa.v26i4.17664

Behnke, R.H. and Muthami, D. 2011. The contribution of livestock to the Kenyan economy (IGAD LPI working paper No. 0311). IGAD Centre for pastoral areas and livestock development (ICPALD), Djibouti. pp. 16-17.

Bornstein, S. and Younan, M. 2013. Significant veterinary research on the dromedary camels of Kenya: Past and Present. $J$. Camelid Sci. 6: 1-48.

Dell'Orto, V., Cattaneo, D., Beretta, E. and Baldi, A. 2000. Effects of trace element supplementation on milk yield and composition in camels. Int. Dairy J. 6(8): $1265-1272$.

https://doi.org/10.1016/So958-6946(01)0oo23-1

FAO. 2017. FAO Statistics, Food and Agriculture organization of the United Nations, Rome, Italy. Accessed on $10^{\text {th }}$ October, 2019 from http://www.fao.org/faostat/en/\#data.

Farah, K.O., Nyariki, D.M., Ngugi, R.K., Noor I.M. and Guliye, A.Y. 2004. The Somali and the camel: Ecology, management and economics. The Anthropologist. 6(1): 45-55. https://doi.org/10.1080/09720073.2004.11890828

Faraz, A., Younas, M., Lateef, M., Yaqoob, M. and Muhammad, G. 2017. Comparative growth performance of Marecha calves (Camelus dromedarius) reared under semi-intensive and extensive management systems. $J$. Anim. plant Sci. 27(4): 1067-1074.
GenStat, 2012. GenStat 15th edition SPI (32bits).

Hashi, A.M., Kamoun, M. and Cianci, D. 1995. Feed requirements of the camel. CIHEAMOptions Mediterraneennes. 13: 71-80.

Huho, J.M., Ngaira, J.K. and Ogindo, H.O. 2011. Living with drought: the case of the Maasai pastoralists of northern Kenya. Edu. Res. 2(1): 779-789.

Iqbal, A. and Khan, B.B. 2001. Feeding behaviour of camel. A review. Pakistan J. Agril. Sci. 38: 58-63.

KNBS. 2019. Kenya population and housing census, volume 11: Distribution of population by administrative units, Kenya National Bureau of Statistics. 52p.

Khan, B.B., Arshad, I. and Riaz, M. 2003. Production and management of camels. PhD Thesis, University of Agriculture, Faisalabad, Pakistan. pp. 108-109.

Kuria, S.G., Wahome, R.G., Gachuiri, C.K. and Wanyoike, M.M. 2004. Evaluation of forages as mineral sources for camels in western Marsabit, Kenya. South African J. Anim. Sci. 34(3): 183-184.

Kurtu, M.Y. 2004. An Assessment of the Productivity for Meat and the Carcass Yield of Camels (Camelus dromedarius) and of the Consumption of Camel Meat in the Eastern Region of Ethiopia. Trop. Anim. Health. Prod. 36(1): 65-76.

Lengarite, M.I., Getachew, G., Akudabweni, L. and Hoag, D. 2014. Supplementary feeding of lactating goats with processed and unprocessed Acacia tortilis pods and local grass in the dry season in northern Kenya. Agril. Sci. Res. J. 4(3): 63-71.

Matofari, J.W. 2013. Analysis of microbial quality and safety of camel (Camelus dromedarius) milk chain and implications in Kenya. $J$. Agril. Ext. Rural Dev. 5(3): 50-54.

Morton, R.H. 1984. Camels for meat and milk production in sub-Sahara Africa. J. Dairy Sci. 67(7): 1548-1553.

https://doi.org/10.3168/jds.Soo22-0302(84)81477-0

Mungai, I.P., Githaiga, W.R. and Wanyoike, M.M. 2010. Correlation of actual live weight and estimates of live weights of camel calves (Camelus dromedarius) in Samburu district of northern Kenya. J. Camelid Sci. 3: 26-32.

Noor, I.M. 2013. Characteristics, feeding and marketing practices of the emerging periurban camel production system in Isiolo County, Kenya, Doctoral dissertation, Egerton University, Kenya. 72p. https://doi.org/10.1186/2041-7136-3-28

Noor, I.M., Bebe, B.O. and Guliye, A.Y. 2012. Analysis of an emerging peri-urban camel production in Isiolo County, northern Kenya. J. Camelid Sci. 5(1): 41-61.

Schwartz, H,J., Dolan, R. and Wilson, A.J. 1983. Camel production in Kenya and its constraints: Productivity. Trop. Anim. Health Prod. 15: 169-178. https://doi.org/10.1007/BF02239929 